\title{
EWOLUCJA OBRAZÓW TOTALITARYZMÓW XX WIEKU NA PRZYKŁADZIE FILMÓW FABULARNYCH ORAZ SERIALI TELEWIZYJNYCH
}

Wiek XX należał do najtragiczniejszych okresów w dziejach ludzkości. W wyniku dwóch wojen światowych, a przede wszystkim realizacji obłędnych ideologii urzeczywistnianych przez ekspansywne państwa totalitarne o charakterze komunistycznym oraz faszystowskim życie straciły miliony ludzi, a kolejne miliony doświadczyły niewyobrażalnych cierpień ${ }^{1}$. Jednym $\mathrm{z}$ istotnych czynników, umożliwiających genezę i rozwój systemów totalitarnych, było umiejętne oddziaływanie propagandowe ich przywódców na opinię publiczną i kształtowanie świadomości społecznej poprzez tradycyjne oraz nowe (wtedy) mass media, których dynamiczny rozkwit przypadał na fundamentalne dekady szerzenia ideologii komunistycznej i faszystowskiej oraz tworzenia pierwszych państw totalitarnych, czyli Związku Sowieckiego, faszystowskich Włoch

Por. S. C o u r t o i s, Zbrodnie komunizmu, (tłum.) A. Nieuważny, w: Czarna księga komunizmu. Zbrodnie, terror, prześladowania, Warszawa 1999, s. 25-26; J. P a j e w s k i, Pierwsza wojna światowa 1914-1918, Warszawa 2005, s. 770; J. H o 1 z e r, Europa wojen 1914-1945, Warszawa 2008, s. 123; N. D a v i e s, Europa walczy 1939-1945, (tłum.) E. Tabakowska, Kraków 2008, s. 356, 380; A. B e e v o r, Druga wojna światowa, (tłum.) G. Siwek, Kraków 2013, s. 958, 966, 973-974. 
i Trzeciej Rzeszy². Na początku lat trzydziestych pojawiło się nawet określenie ludzkości XX wieku jako epoki człowieka masowego ${ }^{3}$. „Nie bez powodu - ruch faszystowski we Włoszech, reżim bolszewicki w Rosji radzieckiej, system nazistowski w Niemczech uwiodły masy społeczne urabiane przez masową propagandę i kontrolowane za pomocą masowego terroru"'. Obok druku, czyli prasy, książki, agitacyjnych plakatów oraz dynamicznie rozwijającej się radiofonii, kino okazało się jednym z najważniejszych, a zarazem najskuteczniejszych narzędzi propagandy, wykorzystywanych do szerzenia ideologii totalitarnych; znaczenie filmu jeszcze bardziej wzrosło wraz z procesem udźwiękowienia i zastosowania wielkiego ekranu, a także ukształtowania swoistego modelu seansu kinowego, polegającego na poprzedzeniu właściwej projekcji upolitycznioną kroniką filmową o charakterze agitacyjnym, indoktrynacyjnym, perswazyjnym, czyli manipulacyjnym ${ }^{5}$.

Przedmiot niniejszego studium stanowi przemiana wizerunku medialnego dwudziestowiecznych totalitaryzmów na przykładzie analizy wybranych, charakterystycznych fabularnych produkcji filmowych, a także telewizyjnych. Badanie zostanie ograniczone do kręgu kultury i cywilizacji europejskiej, czyli będzie zawężone do krytycznej indukcji fenomenów filmowych dotyczących tylko Związku Sowieckiego, faszystowskich Włoch oraz hitlerowskich Niemiec; nie obejmie więc analizy medialnych obrazów odnoszących się do komunistycznych wschodnich państw azjatyckich, np. Chin, Mongolii czy Korei Północnej, a także środkowoamerykańskiej Kuby. Zastosowaną metodę indukcji fenomenologicznej o charakterze jakościowym wzbogaci refleksja metodologiczna specyficzna dla nauk

2 Por. O. T h o m s o n, Historia propagandy, (tłum.) S. Głąbiński, Warszawa 2001, s. 369-372, 374-386.

3 Por. T. G o b a n-K 1 a s, Cywilizacja medialna, Warszawa 2005, s. 35.

4 Tamże.

5 Por. B. D r ew n i a k, Teatr i film Trzeciej Rzeszy. W systemie hitlerowskiej propagandy, Gdańsk 2011, s. 252-255; M. C i eśl i ń s k i, Piękniej niż w życiu. Polska Kronika Filmowa 1944-1994, Warszawa 2006, s. 14; Tenże, Polska Kronika Filmowa. Podglądanie PRL-u, Olszanica-Warszawa 2016, s. 15. 
o mediach i dla teologii środków społecznego przekazu, a szczególnie dla obrazów filmowych ${ }^{6}$.

Strukturę prezentowanego studium stanowią trzy części, uszeregowane zgodnie z zasadą chronologii. Pierwsza dotyczy więc obrazu komunizmu, co wobec przypadającej w 2017 r. setnej rocznicy przewrotu bolszewickiego, który zapoczątkował tworzenie się pierwszego państwa totalitarnego o ustroju komunistycznym, jest dodatkowo uzasadnione; druga poświęcona jest wizerunkom filmowym faszystowskich Włoch, zaś trzecia odnosi się do obrazów ukazujących hitlerowskie Niemcy. Jak już wcześniej zaznaczono, materiałem badawczym będą wyłącznie kinowe i telewizyjne produkcje fabularne; przedstawiona analiza z założenia pomija więc filmy dokumentalne oraz animowane.

\section{FILMOWE OBRAZY EUROPEJSKIEGO KOMUNIZMU}

Do zakończenia drugiej wojny światowej jedynym państwem komunistycznym był Związek Radziecki. W wyniku ekspansji i poparcia sowieckiego władzę w państwach Europy Środkowo-Wschodniej w drugiej połowie lat czterdziestych przejęli komuniści ${ }^{7}$. W owych krajach satelickich, uzależnionych od ZSRR, realizowano polityczne i ekonomiczne idee komunizmu, rozpowszechniane poprzez rozmaite nośniki propagandy, w tym naturalnie również poprzez filmy, a potem seriale telewizyjne. W niniejszej części prezentowanego studium przedstawione zostaną zgodnie z porządkiem chronologicznym najpierw analizy dotyczące kina radzieckiego, a następnie wybranych obrazów niektórych kinematografii krajów środkowo-europejskich ${ }^{8}$.

6 Por. A. A d a m s k i, G. Ł ę c i c k i, Teologia mediów i komunikacji-na styku nauk o mediach oraz nauk teologicznych, ,, Studia Medioznawcze”, nr 2 ( 65 ) 2016, s. 17.

Por. K. K e r s t e n, Europa do drugiej wojnie światowej, w: A. M ą c z a k (red.), Historia Europy, Wrocław 1997, s. 754-755.

8 Prezentowane studium pomija analizę filmów albańskich, bułgarskich i węgierskich oraz obrazów zrealizowanych w krajach powstałych w wyniku rozpadu 


\section{A. Związek Radziecki oraz Rosja}

W określanej obecnie jako kultowa polskiej komedii filmowej Mis $s^{9}$ przypomniane zostało słynne zdanie Lenina o tym, że film to najważniejsza ze sztuk ${ }^{10}$, co naturalnie dotyczyło jej znaczenia nie artystycznego i estetycznego, ale przede wszystkim propagandowego. Co ciekawe, cenzura PRL-u postulowała przeobrażenie owej sceny akcentującej fundamentalną zasadę propagandy komunistycznej ${ }^{11}$. Władze bolszewickie, tworzące od 1917 r. pierwsze w świecie państwo totalitarne, szybko dostrzegły propagandową wartość filmu. W przedrewolucyjnej Rosji kino stanowiło bowiem ulubioną rozrywkę; w carskim imperium w 1916 r. było 3 tysiące kin, a liczba widzów sięgała 150 milionów; w dekadzie 1908-1917 rosyjska kinematografia wyprodukowała ok. 2 tysięcy obrazów, a kina wyświetlały również dziesiątki tysięcy filmów zagranicznych. W 1919 r. bolszewicy znacjonalizowali kinematografię, a od czasu uznania filmu przez Lenina za priorytetowe narzędzie propagandy przeznaczali ogromne sumy na produkcje kronik filmowych i obrazów fabularnych ${ }^{12}$.

Charakterystycznym nurtem ówczesnej kinematografii radzieckiej stały się ekranizacje utworów literackich oraz filmy historyczne ${ }^{13}$. Wśród nich wyróżniały się obrazy ukazujące koszmar caratu. Przykładem takiego filmu był Pancernik Potiomkin ${ }^{14}$, nawiązujący wprawdzie do realnych wydarzeń, czyli buntu marynarzy, ale zawierający

Jugosławii, np. w Słowenii oraz Serbii.

9 Zob. Miś, reż. S. Bareja, 1980 [podstawowe informacje o filmach polskich pochodzą z odpowiednich stron Internetowej Bazy Filmu Polskiego: www.filmpolski.pl, dostępnych od 15 lutego do 11 marca 2017 r.].

10 Por. Kino rosyjskie, w: E. M a ł e k, J. W a w r z y ń c z y k, Kultura rosyjska. Postacie, wydarzenia, symbole, daty, Warszawa 2001, s. 99.

11 Por. M. Ł u c z a k, Miś czyli świat wedtug Barei, Warszawa 2007, s. 153-154.

12 Por. Kino rosyjskie, art. cyt., s. 99-100.

13 Por. tamże, s. 99.

14 Zob. Pancernik Potiomkin, reż. S. M. Eisenstein, 1925 [ podstawowe wiadomości o filmach zagranicznych pochodzą z odpowiednich stron portalu filmweb. pl, dostępnych od 15 lutego do 11 marca 2017 r.]. 
także wymyśloną scenę okrucieństwa, czyli masakrę na odeskich schodach (prześmiewczo pokazaną później w komedii Deja $v u^{15}$ ) oraz wizję upiornego popa jako symbolu zniewalającej religii, będącej sojusznikiem okrutnej władzy. Film miał również fantazyjne, optymistyczne zakończenie. Wymowa propagandowa owego dzieła o niewątpliwych walorach artystycznych była jasna i przejrzysta, bo skonstruowana według prostego schematu: carat, szlachta, oficerowie, duchowieństwo, elita i religia to zło, a komunizm, którego uosobieniem są prości marynarze oraz lud Odessy, to dobro. Trudno też nie zauważyć podobieństwa jednego z marynarzy do Stalina (film został zrealizowany na dwudziestą rocznicę rewolucji 1905 r., a więc w roku 1925, gdy Lenin już nie żył, a Stalin był sekretarzem generalnym sowieckiej partii komunistycznej). Konieczność stosowania przemocy, charakterystyczna dla praktyki rewolucyjnej oraz ideologii komunistycznej, została wyraźnie podkreślona jako jedyny sposób walki o sprawiedliwość społeczną i środek zemsty na ciemiężycielach.

Przykładem nachalnego propagowania ideologii ateistycznego państwa lansującego nową obyczajowość i moralność oraz kształtującego pokolenie nowych ludzi był obraz Kombryg Iwanow, ukazujący w formie prymitywnej komedii perypetie dotyczące cywilnego ślubu córki popa z oficerem Armii Czerwonej ${ }^{16}$. Innym filmem ukazującym w komediowej, ironicznej formie porewolucyjną swobodę obyczajową była Miłość we troje ${ }^{17}$. Warto przypomnieć, że walkę z dawnym porządkiem społecznym, wiarą i religią, tradycyjnymi wartościami etycznymi i normami obyczajowymi bolszewizm prowadził głównie poprzez zmianę prawodawstwa oraz lansowanie poprzez media, a więc i kino, postaw i zachowań dotychczas powszechnie uznawanych za amoralne ${ }^{18}$. Najważniejszym jednak wymiarem propagandy komunistycznej niezmiennie pozostawała sfera wielkiej polityki.

15 Zob. Deja vu, reż. J. Machulski, 1989.

16 Por. J. Pła ż e w s k i, Historia filmu 1895-2005, Warszawa 2010, s. 60.

17 Por. tamże, s. 72; zob. Miłość we troje, reż. A. Room, 1927.

18 Por. G. Ł ę c i c k i, Małżeństwo i rodzina w nauczaniu oraz doświadczeniu Kościoła, Sandomierz 2011, s. 147-151. 
W 1927 r., na dziesięciolecie rewolucji bolszewickiej S. Eisenstein zrealizował monumentalne dzieło pt. Październik ${ }^{19}$. Film o charakterze propagandowym tworzył wizualny mit i sugestywną narrację dotyczącą przewrotu bolszewickiego. Przedstawione obrazy wpisywały się w fałszowanie historii, gdyż najpierw sugerowały, że to bolszewicy obalili carat, a następnie ukazywały rzekome sympatie proreżimowe rządu burżuazyjnego, udającego tylko sprzyjanie demokracji.

Pierwszym obrazem dźwiękowym o przywódcy przewrotu bolszewickiego, nazwanego w propagandzie sowieckiej wielką socjalistyczną rewolucją październikową, był obraz Lenin w październiku ${ }^{20}$, zrealizowany w 1937 r. z okazji dwudziestej rocznicy przejęcia władzy przez bolszewików. Pomijając kwestię ukazania tytułowej postaci w konwencji swoistego świeckiego świętego, nadzwyczaj wrażliwego na ludzką niedolę, czułego, dobrego, skromnego, a przy tym odważnego proroka nowych czasów, przepowiadającego prostym, uciemiężonym ludziom pokój i szczęście, należy podkreślić kontrastującą z tymi cechami zgodę na stosowanie przemocy i zabijanie wrogów, a także kłamliwie ukazywał dawnych towarzyszy Lenina, Zinowiewa, Kamieniewa jako głupców i zdrajców, bo taki ich obraz obowiązywał w propagandzie sowieckiej po rozprawieniu się z nimi przez Stalina $^{21}$. Film nie ujawniał żydowskiej proweniencji i prawdziwych nazwisk przywódców bolszewickich, posługujących się pseudonimami sugerującymi, iż są Rosjanami (Kamieniew to Rosenfeld, Zinowiew to Apfelbaum, Trocki to Bronstejn); ukrywano też, a właściwie jawnie w filmie zaprzeczono żydowskiemu pochodzeniu Lenina $^{22}$. Co ciekawe, w tym obrazie ówczesny dyktator sowiecki, Stalin, był niemal nieobecny, zaledwie wspomniany. Wolno przypuszczać, że odpowiadało to swoistemu mechanizmowi propagandowemu,

19 Zob. Październik, reż. S. Eisenstein, 1927.

20 Zob. Lenin w październiku, reż. M. Romm, 1937.

${ }_{21}$ Por. D. W oł k o g o n o w, Lenin. Prorok raju, apostoł piekła, (tłum.) M. Antosiewicz, Warszawa 2006, s. 167.

22 Por. tamże, s. 38-39. 
lansującemu tezę, iż Stalin to najwierniejszy uczeń Lenina i kontynuator jego dzieła; później pojawiło się propagandowe określenie Stalina jako Lenina naszych czasów ${ }^{23}$. Kolejnym zabiegiem manipulacyjnym było podkreślenie zarówno wodzowskiej funkcji oraz przywódczego charakteru Lenina, jak i jego pokory oraz posłuszeństwa wobec partii. Genialna w swym prymitywizmie scena pokazująca jak zmarznięty Lenin najpierw wzbraniał się przed przyjęciem płaszcza od Dzierżyńskiego, a ustąpił w końcu wobec argumentacji, że to specjalne polecenie Komitetu Centralnego, poraża naiwnością oraz infantylizmem. Plansza z napisem informującym, że po podjęciu wiekopomnej decyzji o konieczności zbrojnej rewolucji Lenin spał na podłodze przykryty cudzym płaszczem wzmacniała komunikat wizualny oraz nasuwała skojarzenia z ideałem ewangelicznego ubóstwa i obrazem proroka nowych czasów ${ }^{24}$.

Analizowany film był przede wszystkim przekazem propagandowym, dla którego rzeczywiste wydarzenie stanowiły tło komunikatów manipulacyjnych. Obraz Lenina przyjeżdżającego z Finlandii (kraju wchodzącego w skład imperium carskiego), można więc powiedzieć obojętnego ideowo dla widzów nie budził tak mocnych i skrajnych negatywnych emocji jak wiadomość prawdziwa o tym, że wcześniej powrót przywódcy bolszewików do Rosji był możliwy dzięki wyrafinowanej polityce Niemiec ${ }^{25}$. Film akcentował bojowe, rewolucyjne nastawienie Lenina i naturalnie pomijał milczeniem niedawne wydarzenia, czyli jego dwuznaczną postawę podczas manifestacji w Piotrogrodzie w lipcu 1917 r. ${ }^{26}$ Kłamliwy filmowy wizerunek miał na celu budowanie legendy oraz mitu Lenina jako wodza rewolucji i proletariatu. Kolejnym mechanizmem manipulacyjnym było więc ukazywanie Lenina jako pracowitego, odważnego ideowca któremu nie straszne były uciążliwości związane z egzystencją konspiratora i rewolucjonisty poszukiwanego przez policję. W rzeczywistości

\footnotetext{
23 Por. M. K u 1 a, Religiopodobny komunizm, Kraków 2003, s. 154-155.

24 Por. Mt 10, 10.

25 Por. D. W o ł k o g o n o w, dz. cyt., s. 139-142.

26 Por. tamże, s. 156-157.
} 
Lenin, nawykły raczej do luksusu i beztroskiego życia, nigdy nie pracujący, źle znosił trudy walki politycznej oraz rutynowych obowiązków i choć innych wzywał do walki, to sam się jednak nie narażał. Film, choć nawiązywał do nadzwyczajnego posiedzenia Komitetu Centralnego w dniu 10 października 1917 r., to pomijał fakt uczestniczenia w nim Trockiego (Bronstejna), czyli drugiego po Leninie przywódcy partii, który w 1929 r. jako kontrrewolucjonista został deportowany ze Związku Sowieckiego i przez Stalina był uważany za głównego wroga ${ }^{27}$. Taki zabieg manipulacyjny, określany jako przemilczenie, miał na celu przedstawienie Lenina jako jedynego lidera bolszewików i bohatera rewolucji. Podkreśleniu jego cech pozytywnych, czyli wizerunku jowialnego, wrażliwego, szlachetnego człowieka, służyło zestawienie z obrazem przeciwnika politycznego, premiera Rządu Tymczasowego, Kiereńskiego, który został przedstawiony jako osoba upiorna, nieszlachetna, najchętniej (i nieudolnie) posługująca się podstępem i siłą. Znaczące, że akurat wykorzystanie siły i przemocy w przypadku Lenina stanowiło jego walor.

Filmowe wizerunki komunistycznego dyktatora ZSRR, czyli Stalina, przeszły swoistą ewolucję. Podobieństwa i powiązania z cechami Lenina były naturalnie oczywiste i jednoznaczne. Stalin bywał przedstawiany nie tylko tak samo jak Lenin jako uosobienie mądrości, roztropności, energii, zdecydowania, dalekowzroczności, ale również stawał się postacią niemal deifikowaną. Przykładem kreowania takiego wizerunku był film Przysięga ${ }^{28}$, prezentujący obraz Stalina jako nowego mesjasza. W kolejnym dziele tego samego reżysera Stalin ponownie został przedstawiony jako zbawca, tym razem samolotem przybywający z nieba na ziemię w szatach jasnych, na podobieństwo anielskich ${ }^{29}$. Choć postać Stalina pojawiała się w wielu filmach

27 Por. tamże, s. 125-126,155-156, 159, 166-167; Tenże, Stalin. Wirtuoz kłamstwa, dyktator myśli, (tłum.) M. Antosiewicz, Warszawa 2006, s. 311-315, 800.

28 Zob. Przysięga, reż. M. Cziaureli, 1946;

Przysięga: https://pl.wikipedia.org/wiki/Przysi\%C4\%99ga_film_1946; (data dostępu: 25 lutego 2017); por. M. K u la, dz. cyt., s. 67.

29 Zob. Upadek Berlina, reż. M. Cziaureli, 1949; Upadek Berlina: https://pl.wikipedia. org/wiki/Upadek_Berlina (data dostępu: 25 lutego 2017); por. M. K u 1 a, dz. cyt., s. 67. 
socrealistycznych, to jednak nie bywał on tytułowym bohaterem, tak jak wódz rewolucji, któremu poza wspomnianym wyżej poświęcono jeszcze następujące obrazy: Lenin w 1918 roku ${ }^{30}$, Lenin w Polsce ${ }^{31}$, Lenin $w$ Paryż $u^{32}$. Nie znaczy to jednak, że Stalin nie był główną postacią rozmaitych filmów. Obrazy Wielka tuna ${ }^{33}$ oraz Niezapomniany rok $1919^{34}$ wyolbrzymiały rolę Stalina podczas rozmaitych epizodów z okresu rewolucji bolszewickiej i miały służyć kreowaniu i utrwalaniu mitu wodza ${ }^{35}$. Za swoistą ironię losu wolno uznać to, że etatowo obsadzany w roli dyktatora gruziński aktor Michaił Gelowani zmarł w 1956 r. w dniu urodzin Stalina, czyli 21 grudnia.

Po śmierci dyktatora (1953 r.) i ujawnieniu jego niezliczonych zbrodni pokazywanie go na ekranie nastręczało niemało problemów. Radzieccy twórcy filmowi mimo destalinizacji nie zawsze mogli pominąć osobę tyrana, szczególnie w produkcjach dotyczących drugiej wojny światowej, a raczej tzw. wielkiej wojny ojczyźnianej, toczonej przez ZSRR z hitlerowskimi Niemcami w latach 1941-1945. Propaganda sowiecka, jak i później PRL-owska pomijała bowiem milczeniem sojusz niemiecko-radziecki zawarty w sierpniu 1939 r., który stanowił genezę drugiej wojny światowej i był podstawą ataku obu mocarstw totalitarnych na Polskę we wrześniu 1939 r. i jej czwartego rozbioru ${ }^{36}$.

Radzieckie kino w epoce tzw. odwilży po XX Zjeździe KPZR koncentrowało się na sugestywnym pokazywaniu dramatów pojedynczych, zwykłych uczestników wojny, przeważnie szeregowych żołnierzy i ich rodzin. Zrealizowane wtedy piękne obrazy, np. Leca

\footnotetext{
30 Zob. Lenin w 1918 roku, reż. M. Romm, 1939.

31 Zob. Lenin w Polsce, reż. S. Jutkiewicz, 1965.

32 Zob. Lenin w Paryżu, reż. S. Jutkiewicz, 1981.

33 Zob. Wielka tuna, reż. reż. M Cziaureli, 1938.

34 Zob. Niezapomniany rok 1919, reż. M Cziaureli, 1952.

35 Por. J. W oj n i c k a, Dzieci XX Zjazdu. Film w kulturze sowieckiej lat 1956-1968, Kraków 2012, s. 19-20.

36 Por. R. M o o r h o u s e, Pakt diabłów. Sojusz Hitlera i Stalina, (tłum.) G. Siwek, Kraków 2015, s. 57-58, 65-76.
} 
żurawie ${ }^{37}$ Ballada o żołnierzu ${ }^{38}$, Los człowieka ${ }^{39}$ cechowały się wyraźnym przesłaniem antywojennym i całkowitym pomijaniem kwestii stalinizmu; inaczej również, bo w konwencji melodramatycznej i kameralnej pokazywały bohaterstwo i patriotyzm pozbawiony zbędnego patosu ${ }^{40}$. W tworzonych później tzw. superprodukcjach przedstawiających przebieg wielkich bitew nie sposób było jednak pominąć osobę głównodowodzącego Armią Czerwoną, czyli Stalina. W wielkich epopejach filmowych takich jak Wyzwolenie ${ }^{41}$ oraz Bitwa $o$ Moskwę $e^{42}$ kremlowski despota jawił się oczywiście nie jako nie tyran, dyktator, zbrodniarz polityczny, sprawca milionów dramatów i tragedii, autokrata najchętniej posługujący się terrorem wobec własnego społeczeństwa, ale jako uosobienie spokoju, rozwagi, mądrości, wiedzy militarnej, taktyki i strategii, czyli wódz podejmujący jedynie słuszne decyzje. Formą komunikatów wizualnych mających przekazywać właśnie taki wizerunek Stalina były sceny narad z politykami, generałami i marszałkami ZSRR; ich ożywione, czasem gorące dyskusje i spory były najpierw uważnie obserwowane przez Stalina najczęściej milczącego, przechadzającego się po kremlowskich komnatach wolnym, dostojnym krokiem, spokojnie palącego fajkę, głęboko zamyślonego, czasem dopytującego o jakieś szczegóły, a następnie wydającego rozkazy o historycznym znaczeniu, czyli skutkujące zwycięstwami armii radzieckiej, a klęskami wojsk niemieckich, co jednak nie zawsze było zgodne z prawdą historyczną ${ }^{43}$.

Po rozpadzie Związku Radzieckiego (1991 r.) kinematografia rosyjska uzyskała możliwość swobody twórczej i pokazywania tematów uprzednio zakazanych przez cenzurę. Nieco wcześniej zauważalnym sygnałem przemian politycznych oraz liberalizacji ustroju stał się

37 Zob. Leca żurawie, reż. M. Kałatozow, 1957.

38 Zob. Ballada o żotnierzu, reż. G. Czuchraj, 1959.

39 Zob. Los człowieka, reż. S. Bondarczuk, 1959.

40 Por. J. Woj n i c k a, dz. cyt., s. 57.

${ }^{41}$ Zob. Wyzwolenie, reż. J. Ozierow, 1969.

42 Zob. Bitwa o Moskwę, reż. J. Ozierow, 1985.

43 Por. B. S o k o ło w, Prawdy i mity Wielkiej wojny Ojczyźnianej 1941-1945, (tłum.) J. Strogonowa, A. Sawinkow, Kraków 2013, s. 179-198. 
obraz Pokuta44; dzieło gruzińskiego reżysera w formie groteskowej, symbolicznej i niemal surrealistycznej stanowiło jawną krytykę dyktatorskiej władzy, rządów totalitarnych, ale przede wszystkim sprawującego je satrapy, w czym trudno było nie dostrzegać aluzji do Stalina. Telewizyjny serial Dzieci Arbatu ${ }^{45}$ stanowiący ekranizację cyklu głośnych powieści Anatolija Rybakowa, które wydane w ZSRR dopiero pod koniec lat 80-tych zwiastowały systemowe przeobrażenia, również ukazywał przede wszystkim lata wielkiego terroru ${ }^{46}$ i grozę systemu, w którym nikt, poza dyktatorem, nie był bezpieczny. Koszmarny obraz zniewolonego społeczeństwa, sparaliżowanego strachem, łatwo poddającego się indoktrynacji ideologicznej niewiele wspólnego mającej z logiką i poczuciem przyzwoitości, obraz prześladowań nawet wysokich dygnitarzy partyjnych, polityków, wojskowych, towarzyszy Lenina i zwykłych obywateli uzupełniony został przedstawieniem upadku moralności, skutkującego swobodą obyczajową, donosicielstwem, fałszem, zdradą ${ }^{47}$. Na tle losów tytułowych bohaterów wyraźnie przypomniano główne wydarzenia polityczne z historii ZSRR z lat 1934-1943, a więc zabójstwo Kirowa, Ordżonikidze, procesy Kamieniewa, Zinowiewa, Bucharina, Tuchaczewskiego zakończone wyrokami śmierci, a także początkowe lata wojny z Niemcami; $w$ fabułę serialu wpleciono również porażające informacje o ogromie zbrodni sowieckich ${ }^{48}$. Serial pokazywał także Stalina; jego wizerunek przeważnie opatulonego ciepłym, grubym szalem, jakby schorowanego, przedwcześnie postarzałego, popijającego herbatę i palącego fajkę, kontrastował z budzącym grozę spojrzeniem oraz irracjonalnymi decyzjami. Stalin został bowiem przedstawiony jako omylny polityk i marny strateg ${ }^{49}$, a jednocześnie

\footnotetext{
44 Zob. Pokuta, reż. T. Abuładze, 1987.

45 Zob. Dzieci Arbatu, reż. A. Eszpaj, 2004.

46 Por. J. B a b e r o w s k i, Czerwony terror. Historia stalinizmu, (tłum.) J. Antkowiak, Warszawa 2009, s. 110.

47 Por. D. R. M a r p le s, Historia ZSRR od rewolucji do rozpadu, (tłum.)
}

I. Scharoch, Wrocław 2006, s. 137-143;

48 Zob. Dzieci Arbatu, dz. cyt., odc. 9, 12.

49 Zob. tamże, odc. 3 i 15. 
jako skryty, podstępny wiarołomny mistrz intryg, zręczny manipulator dzierżący nieograniczoną władzę wyłącznie w swoich rękach ${ }^{50}$; znakiem jego zwyrodniałej osobowości stała się scena obrzucania wyzwiskami fotografii syna na wieść, że dostał się on do niemieckiej niewoli ${ }^{51}$.

Warto zauważyć, że w serialu pokazano grozę zsyłki, a nie łagru oraz całkowicie pominięto fakt napaści ZSRR na Polskę we wrześniu i na Finlandię w grudniu 1939 r.; omawiany cykl utrwalał więc propagandowy obraz wojny. Scena przedstawiająca Stalina oglądającego w pierwszej połowie 1941 r. niemieckie kroniki filmowe prezentujące triumfy Hitlera zawierała wypowiedź kremlowskiego dyktatora: „Z nim będziemy się przyjaźnić”, ${ }^{2}$. Użyta forma czasu przyszłego nie odpowiadała jednak historycznej prawdzie; Stalina niemal od dwóch lat łączył bowiem pakt z Hitlerem, przypieczętowany rozbiorem Polski i podziałem strefy wpływów w Europie Środkowo-Wschodniej. Niemiecko-sowiecka współpraca była faktem, więc słowa radzieckiego przywódcy należałoby interpretować jako znak totalnego zaślepienia i niewiary w zagrożenie ze strony tak wypróbowanego sojusznika.

Co ciekawe, we współczesnych filmach rosyjskich przedstawiających epokę stalinowską, można zauważyć swoistą ambiwalencję w odniesieniu do wizerunku kremlowskiego dyktatora. Pokazywaniu zbrodni, niesprawiedliwości, terroru, towarzyszy niekiedy swoista rehabilitacja, a nawet jakby usprawiedliwianie Stalina. W ostatniej części filmowego cyklu Spaleni słońcem ${ }^{53}$, opowiadającego o losach ideowego bolszewika, pułkownika Armii Czerwonej, ofiary stalinowskiego terroru, niesłusznie aresztowanego, torturowanego, skazanego za niepopełnione winy, umieszczona została scena jego spotkania

50 Por. P. K e n e z, Odkłamana historia Związku Radzieckiego, (tłum.) A. Górska, Warszawa 2008, s. 128-129.

51 Zob. Dzieci Arbatu, dz. cyt., odc. 16.

52 Zob. tamże, odc. 15.

53 Zob. Spaleni słońcem, reż. N. Michałkow, 1994; Spaleni słońcem 2, reż. N. Michałkow, 2010, Spaleni słońcem 2. Cytadela, reż. N. Michałkow, 2011. 
ze Stalinem, potrzebującym na froncie doświadczonych dowódców. Stalin doskonale wiedział, że ów oficer był niewinny, że może być zawiedziony i pragnąć sprawiedliwości, i jakby uprzedzając naturalne pytania swej ofiary o przyczynę prześladowań, a następnie rehabilitacji i awansu odpowiadał przewrotnie: „Za co ciebie (...) wsadzono do więzienia, zesłano do łagru, omal nie rozstrzelano. Chcesz spytać, dlaczego teraz cię wypuszczono i nadano stopień generała, tak? Ale za co i dlaczego - to złe pytania. Właściwe pytanie brzmi: po co? A wsadzili cię po to, żeby w odpowiednim czasie wypuścić"54. Makiaweliczna logika dyktatora była poprzedzona wcześniej wyrażonym postulatem naprawienia błędów wobec owego starego bolszewika ${ }^{55}$, także mającego na sumieniu wiele zbrodni z okresu rewolucji i wojny domowej. Taka wizja stalinizmu mogła sugerować pewien determinizm historyczny o wymiarze powszechnym, zacierający granice między dobrem a złem, katem a ofiarą, i przekonujący o znikomości ludzkiego losu wobec tragizmu dziejów państwa ${ }^{56}$. Taka interpretację wydaje się uzasadniać historia oficera NKGB najpierw aresztującego owego bohatera bolszewickiego, a następnie poszukującego go na rozkaz Stalina w celu uniewinnienia i awansowania. Wykonujący owe polecenia oficer NKGB sam w końcu stał się ofiarą systemu, którego był funkcjonariuszem; należy się domyślać, że oskarżony fałszywie o szpiegostwo niewątpliwie został rozstrzelany. W takim obrazie granica między winą a niewinnością, rozsądkiem a absurdem, sensem a nonsensem wydaje się niemal nie istnieć. Ślepy los, fatum, przymus tworzyły ideologię konieczności dziejowej, usprawiedliwiającej Stalina i stworzony przez niego system zbrodni. Taki obraz, nadal obecny w kulturze popularnej po upadku komunizmu i rozpadzie ZSRR nie tylko fałszuje prawdę historyczną, ale przede wszystkim stanowi jeden z elementów aktualnej propagandy światopoglądu utylitarystycznego oraz relatywistycznego.

\footnotetext{
54 Spaleni stońcem 2. Cytadela, dz. cyt.

55 Zob. Spaleni słońcem 2, dz. cyt.

56 Por. Ł. D e m b y, Harmonia świata. Twórczość filmowa Nikity Michałkowa, Kraków 2009, s. 293-294.
} 
Prawda o zbrodniach bolszewickich i stalinowskim terrorze bywa przez rosyjską kinematografię jednak i wiarygodnie ukazywana; obraz zagłady niemieckich jeńców wojennych przedstawiony został w filmie Jeńcy ${ }^{57}$; serial Karny batalion ${ }^{58}$ ukazywał tragiczne dzieje łagierników zmuszanych do walki na najtrudniejszych odcinkach frontu; obraz Admirat ${ }^{59}$ oraz Żyła sobie baba ${ }^{60}$ przypominały okrucieństwo bolszewików z czasów rewolucji i wojny domowej. Wizerunek powszechnego zakłamania oraz ateizacji społeczeństwa radzieckiego $\mathrm{w}$ okresie międzywojennym prezentowała zrealizowana $\mathrm{z}$ rozmachem $\mathrm{w}$ formie serialu wierna ekranizacja arcydzieła Michaiła Bułhakowa Mistrz i Małgorzata ${ }^{61}$. Filmowy musical Bikiniarze ${ }^{62}$ wyraźnie akcentował konfrontację między ideologią totalitarną a pragnieniem wolności wyrażaną w subkulturze powojennej młodzieży moskiewskiej. Dramat polityczny Kierowca dla Wiery ${ }^{63}$ dobitnie przypominał zaś, że komunizm pozostał systemem totalitarnym również po śmierci Stalina; zmiana rządzącej ekipy nie oznaczała bowiem porzucenia zbrodniczych metod i praktyk systemu, nadal zagrażającego wszystkim obywatelom, a więc i przedstawicielom niższych szczebli władzy. Podkreślona wszechmoc KGB nawet wobec wysokiej rangi wojskowego przypominała o znaczeniu tajnej policji politycznej jako głównego instrumentu niszczenia wrogów sowieckiego ustroju ${ }^{64}$.

Wiarygodne filmowe wizje komunizmu ukazywane w kinie rosyjskim po 1991 r. wciąż się jednak muszą zmagać z dawnymi radzieckimi obrazami propagandowymi, które nadal są obecne w kulturze popularnej i przekazach medialnych.

\footnotetext{
57 Zob. Jeńcy, reż. A. Antonow, 2005

58 Zob. Karny batalion, reż. N. Dostal, 2004.

59 Zob. Admirat, reż. A. Krawczuk, 2008.

60 Zob. Żyła sobie baba, reż. A. Smirnow, 2011.

${ }_{61}$ Zob. Mistrz i Małgorzata, reż. W. Bortko, 2005.

62 Zob. Bikiniarze, reż. W. Todorowski, 2008.

63 Zob. Kierowca dla Wiery, reż. P. Czuchraj, 2004.

${ }^{64}$ Por. C. A n d r e w, O. G or d ij e w s k i, $K G B$, (tłum.) R. Brzeski, Warszawa 1999, s. 43.
} 


\section{B. Polska}

Władze komunistyczne Polski Ludowej zdawały sobie sprawę z niskiego poparcia społecznego wobec komunizmu. Propagowaniu nowego ustroju i systemu centralnie sterowanej gospodarki towarzyszyło tworzenie propagandowych mitów i fałszywych obrazów najnowszej historii. Swoistą formą kłamliwego przedstawiania walki konspiracyjnej było pomijanie rzeczywistych zasług Armii Krajowej na rzecz afirmowania aktywności partyzantki komunistycznej, czyli najpierw Gwardii, a potem Armii Ludowej. Za film wpisujący się w ten nurt propagandowy należy uznać Pokolenie ${ }^{65}$ A. Wajdy. Obraz choć zakłamywał historię, to pod względem artystycznym znacznie odbiegał od dotychczas realizowanych i kreślił sugestywny wizerunek charakterystycznych bohaterów młodego pokolenia ${ }^{66}$.

Za typowy wytwór komunistycznej propagandy filmowej w okresie polskiego stalinizmu należy uznać obraz Wandy Jakubowskiej Żołnierz zwycięstwa ${ }^{67}$, stanowiący monumentalną ekranową biografię generała Karola Świerczewskiego. Film o charakterze mitotwórczym miał na celu idealizację nieprawdziwego bohatera, który w rzeczywistości był komunistycznym zbrodniarzem, sowieckim agentem, nieudolnym dowódcą, a ponadto alkoholikiem ${ }^{68}$. Filmowy „Walter” jawił się jednak nie tylko jako heros, geniusz strategii i taktyki, wcielenie patriotyzmu, przenikliwości politycznej, żołnierskiego męstwa i odwagi, ale przede wszystkim jako uosobienie charyzmatycznego przywódcy, wychowawcy młodszych oficerów, wcielenie sprawiedliwości i dobroci. Do ulubionych narzędzi propagandy totalitarnej należały fotografie i sceny ukazujące przywódców z dziećmi jako symbolami niewinności i przyszłości narodu. W filmie Żotnierz zwycięstwa nie mogło więc zabraknąć owego motywu. Jedna z pierwszych scen

65 Zob. Pokolenie, reż. A. Wajda, 1954.

66 Por. P. Ś m i ało w s k i, Tadeusz Janczar. Zawód: aktor, Warszawa 2007, s. 60 .

67 Zob. Żotnierz zwycięstwa, reż. W. Jakubowska, 1953.

68 Por. T. Pł u ż a ń s k i, Lista oprawców, Warszawa bdw, s. 406-409. 
przedstawiała zapracowanego generała, dzielnie zmagającego się z licznymi obowiązkami, cierpliwie jednak wysłuchującego dziecięcego meldunku i obiecującego odwiedzenie szkoły. Motyw ten przypominał historię ewangeliczną o uczniach nie dopuszczających dzieci do Chrystusa ${ }^{69}$; w analizowanym filmie negatywną rolę spełnia adiutant $\mathrm{i}$ on również jest skarcony przez generała.

Jak wyżej wspomniano, sowiecka inwazja na Polskę i dokonany przez hitlerowskie Niemcy oraz stalinowski Związek Radziecki czwarty rozbiór Rzeczypospolitej stanowił do końca istnienia PRL-u temat zakazany, podobnie jak i sowiecka agresja na Finlandię w 1939 r. Propaganda Polski Ludowej, dla której wojna i okupacja stanowiła jeden z głównych tematów historycznych, nakierowana była na propagowanie oraz utrwalanie kłamliwej wizji dziejów najnowszych, m. in. przemilczenie agresji ZSRR we wrześniu 1939 r., i gehenny Polaków żyjących pod okupacją sowiecką w latach 1939-1941, czyli do wybuchu wojny niemiecko-radzieckiej ${ }^{70}$.

Jako przykład realizacji takiej fałszywej wizji historii najnowszej i przebiegu drugiej wojny światowej wolno przypomnieć początek telewizyjnej epopei o polskich czołgistach. Bohaterski polski młodzieniec, Janek Kos, który w poszukiwaniu ojca, walczącego na Westerplatte przemierzał ZSRR, był na Kaukazie, a potem znalazł się w tajdze, na wieść o tworzeniu się polskiej armii w ZSRR w 1943 r. wyruszył do miejsca jej formowania. Wcześniej jednak stoczył bójkę z krewkim Gruzinem, Grigorijem, przekonanym, że wojna rozpoczęła się dopiero w 1941 roku; Janek zaś opowiadając o agresji niemieckiej na Polskę w 1939 r. oczywiście nie wspomniał o drugim najeźdźcy, czyli ZSRR; podobnie początek wojny tłumaczył później $\mathrm{W}$ pociągu szeregowemu czerwonoarmiście ${ }^{71}$. W kolejnym odcinku serialu o pancernych dwukrotnie umieszczony został komunikat

69 Por. Mt 19, 13-14.

70 Por. C. Grzela k, Kresy w czerwieni. Agresja Związu Sowieckiego na Polskę w 1939 roku, Warszawa 2001, s. 6.

${ }^{71}$ Zob. Czterej pancerni i pies, odc. 1: Załoga, reż. K. Nałęcki, 1966. 
o tym, że Bug stanowił polską granicę ${ }^{72}$, co naturalnie było niezgodne $\mathrm{z}$ faktami i wpisywało się $\mathrm{w}$ propagandę wymazywania ze zbiorowej świadomości pamięci o Kresach Wschodnich. W żadnym filmie ani serialu wojennym, wyprodukowanym w okresie Polski Ludowej, nawet ukazującym lub wspominającym losy Polaków przybyłych ze Wschodu, nie wyjaśniono, skąd owi rodacy tam się znaleźli ${ }^{73}$.

Najprawdopodobniej pierwszym obrazem wspominającym o agresji sowieckiej na Polskę w 1939 r. był telewizyjny film Virtuti ${ }^{74}$. Dopiero kinematografia i telewizja III RP pozbawiona destrukcyjnych ograniczeń cenzuralnych mogła ukazać prawdę historyczną o zbrodniach sowieckich popełnianych na Polakach podczas wojny i okupacji, jak i w latach powojennych, a także o terrorze komunistycznym w okresie Polski Ludowej. Jako przykłady produkcji fabularnych i serialowych odkłamujących narrację propagandowo-historyczną PRL-u należy wymienić filmy o losach polskich zesłańców: Cynga ${ }^{75}$, Syberiada polska ${ }^{76}$; o zbrodni katyńskiej i jej fałszowaniu: Katyńn ${ }^{77}$, o dramacie żołnierzy AK: Pierścionek z orłem w koronie $^{78}$, Generat $\mathrm{Ni}^{79}$, o tragedii żołnierzy wyklętych: Deszczowy żolnierz ${ }^{80}$, Historia Roja ${ }^{81}$; również seriale telewizyjne: Czas honoru ${ }^{82}$ oraz Bodo ${ }^{83}$ przedstawiały prawdę o zbrodniczym charakterze komunizmu. Obraz

72 Zob. Czterej pancerni i pies, odc. 2: Radość i gorycz, reż. K. Nałęcki, 1966. Warto zauważyć, że ingerencja cenzury zawoalowała owe komunikaty. Por. M. Ł a z a r z, Czterej pancerni i pies. Przewodnik po serialu i okolicach, Wrocław 2006, s. 39.

73 Zob. Nieznany, reż. W. Lesiewicz, 1964; Jarzębina czerwona, reż., E. C. Petelscy, 1969.

74 Zob. Virtuti, reż. J. Butrymowicz, 1989.

75 Zob. Cynga, reż. L. Wosiewicz, 1991.

76 Zob. Syberiada polska, reż. J. Zaorski, 2013.

77 Zob. Katyń, reż. A. Wajda, 2007.

78 Zob. Pierścionek z orłem w koronie, reż. A. Wajda, 1992.

79 Zob. Generat Nil, reż. R. Bugajski, 2009.

80 Zob. Deszczowy żotnierz, reż. W. Saniewski, 1996.

${ }^{81}$ Zob. Historia Roja, reż. J. Zalewski, 2016.

82 Zob. Czas honoru, reż. M. Kwieciński i in., 2008-2013,

83 Zob. Bodo, odc. 13, reż. M. Kwieciński, 2016. 
Prymas. Trzy lata z tysiaca ${ }^{84}$ ukazywał stalinowskie represje wobec Kościoła. Należy jednak przypomnieć, że już wcześniej polscy filmowcy podejmowali temat terroru stalinowskiego; premiery filmów Przesłuchanie ${ }^{85}$, Matka Królów ${ }^{86}$ były jednak przez lata wstrzymywane przez cenzurę ${ }^{87}$. Nie dopuściła ona również do realizacji filmu o powojennych losach akowców, skazanych na wegetację i zmuszanych do donosicielstwa ${ }^{88}$. Nieprawość panująca w epoce stalinizmu została pokazana m. in. w filmie Życie raz jeszcze ${ }^{89}$ o polskim lotniku, który po wojnie wrócił do kraju, w sensacyjno-szpiegowskim obrazie Orzet i reszk $a^{90}$ o oficerze AK podejmującym w czasach tzw. odwilży współpracę z wywiadem PRL, a także w filmie Człowiek z marmuru ${ }^{91}$ o przodowniku pracy socjalistycznej. Popularne seriale telewizyjne o tematyce wojennej wyprodukowane w PRL-u wciąż cieszą się dużą popularnością, czasem budzą kontrowersje, a niekiedy są nawet określane mianem kultowych ${ }^{92}$, lecz wobec ujawnienia prawdy historycznej w fikcyjnych motywach ${ }^{93}$ traktowane są przede wszystkim jako przekazy rozrywkowe, a nie historyczno-propagandowe. Inne, pełne obłudy i łatwo rozpoznawalnego fałszu, zostały niemal całkowicie zapomniane ${ }^{94}$.

84 Zob. Prymas. Trzy lata z tysiąca, reż. T. Kotlarczyk, 2000.

85 Zob. Przestuchanie, reż. R. Bugajski, 1982.

86 Zob. Matka Królów, reż. J. Zaorski, 1982.

87 Por. G. Ł ę c i c k i, Cenzura w Polsce Ludowej: propaganda, manipulacja, destrukcja, „Kwartalnik Nauk o Mediach”, 2015 nr 2: http://knm.uksw.edu.pl/ cenzura-w-polsce-ludowej-propaganda-manipulacja-destrukcja/ (data dostępu: 28.02.2017).

88 Por. T. L u b e $1 \mathrm{~s}$ k i, Historia niebyła kina PRL, Kraków 2012, s. 94-102.

89 Zob. Życie raz jeszcze, reż. J. Morgenstern, 1964.

90 Zob. Orzet i reszka, reż. R. Filipski, 1974.

91 Zob. Człowiek z marmuru, reż. A. Wajda, 1976.

92 Por. P. K. P i o t r o w s k i, Kultowe seriale, Warszawa 2011, s. 7-9, 69-82

93 Por. M. R e ple w i c z, Stawka większa niż kłamstwo, Warszawa 2015, s. 7-8.

94 Zob. Podziemny front, reż. S. Nowicki, H. Drapella, 1965; Dyrektorzy, reż. Z. Chmielewski, 1975. 


\section{Słowacja}

Kino słowackie stosunkowo rzadko sięga po tematykę historyczną. Po latach czechosłowackich produkcji socrealistycznych i obyczajowych za swoisty ewenement należy więc uznać obraz Czerwony kapitan $^{95}$, który jest wprawdzie filmem kryminalnym, ale w sposób wyjątkowo drastyczny ukazuje jeden z wymiarów komunistycznego terroru, a mianowicie działania tajnych służb wymierzone przeciwko Kościołowi. Obraz skandali obyczajowych, mechanizmów szantażu i łamania sumien, systemu donosicielstwa i okrutnych tortur, wprowadzania agentów do hierarchii kościelnej, zapewnianie bezkarności dawnym oprawcom wielce przypomina analogiczne zjawiska z dziejów PRL-u, a szczególnie osławionego IV Departamentu $\mathrm{MSW}^{96}$, a także historii III RP ukazywanej na kinowych i telewizyjnych ekranach ${ }^{97}$.

\section{Czechy}

Kontynuując niejako w sposób naturalny tradycje kinematografii czechosłowackiej aktualne kino czeskie, jak i słowackie, niezbyt często sięga po tematykę historyczną, wpisującą się w nurt rozliczeniowy z totalitaryzmem. Współczesne obrazy ukazują przede wszystkim rozmaite problemy społeczne wynikające z upadku komunizmu. Porażające obrazy czeskiej prowincji ${ }^{98}$, wizerunki osób borykających się z dramatycznymi doświadczeniami i dylematami ${ }^{99}$ bywają lagodzone poprzez produkcje przedstawiające przemiany obyczajowe i mentalne zachodzące pośród Czechów ${ }^{100}$, ukazywanych w sposób żartobliwy i dobrotliwy ${ }^{101}$.

95 Zob. Czerwony kapitan, reż. M. Kollar, 2016.

96 Por. H. D o m i n i c z a k, Organy bezpieczeństwa PRL w walce z Kościołem katolickim 1944-1990 w świetle dokumentów MSW, Warszawa 2000, s. 393-404.

97 Zob. Stużby specjalne, reż. P. Vega, 2014.

98 Zob. Dzikie pszczoty, reż. B. Sláma, 2001.

99 Zob. Reguły kłamstwa, reż. R. Sedláček, 2006.

100 Zob. Święta czwórca, reż. J. Hřebejk, 2012.

101 Zob. Butelki zwrotne, reż. J. Svěrák, 2007. 
Swoistą komediową wizję czeskiego stalinizmu przedstawiał film Czołgowy batalion ${ }^{102}$, zrealizowany jeszcze przed podziałem Czechosłowacji i w pewnym sensie nawiązujący do poetyki ekranizacji Przygód dobrego wojaka Szwejka ${ }^{103}$. Absurd wojskowego drylu zmieszany z ideologicznymi nonsensami tworzył zabawny, choć nie pozbawiony grozy i goryczy, ironiczny, a zarazem groteskowy obraz konfrontacji zdrowego rozsądku z nierealną rzeczywistością, będącą efektem komunistycznego światopoglądu, utopijnego ustroju i autentycznego terroru.

Dramatyczny wizerunek stalinizmu został znakomicie ukazany w filmie kryminalnym $W$ cieniu $^{104}$, sugestywnie przedstawiającym ponurą egzystencję w państwie totalitarnym, w którym terror, niesprawiedliwość, kłamstwo stanowiły narzędzia władzy także wobec jej funkcjonariuszy, a uczciwość i prawda była skazana na porażkę. Wspomniany obraz podkreślał fałszywe przesłanki bolszewickiej ideologii redukującej człowieka jedynie do roli małego, pozbawionego większego znaczenia i wartości elementu proletariackiego kolektywu w maszynerii totalitarnego państwa. Akcentował także ideologię i praktyki antysemickie występujące w stalinizmie. Film o udziale czeskich lotników w bitwie o Anglię ${ }^{105}$ przypominał natomiast o ich późniejszych prześladowaniach po powrocie do ojczyzny rządzonej przez komunistów.

\section{E. Rumunia}

Kinematografia rumuńska, przeżywająca u progu pierwszej dekady XXI w. swoisty renesans, zajmowała się głównie problematyką społeczną $^{106}$. Obrazem o tematyce historycznej, ukazującym koszmar

102 Zob. Czołgowy batalion, reż. V. Olmer, 1991.

103 Zob. Dobry wojak Szwejk, reż. K. Steklý, J. Trnka, 1956.

104 Zob. W cieniu, reż. D. Ondřŕček, 2012.

105 Zob. Ciemnoniebieski świat, reż. J. Svěrák, 2001.

106 Zob. Dobre chęci, reż. A. Sitaru, 2011; Wszyscy w naszej rodzinie, reż. J. Rude, 2012. 
komunizmu był Gang Rosenthala ${ }^{107}$, stanowiący koprodukcję kilku kinematografii, w tym polskiej, ale stworzony przez rumuńskiego reżysera. Kryminalna akcja stanowiła tło do ukazania antysemickiego nurtu obecnego $\mathrm{w}$ rumuńskim totalitaryzmie i formowania się jego nacjonalistycznej wersji mimo destalinizacji. Oparty na faktach obraz sfingowanego procesu, wymuszania zeznań, bezwzględności władzy przypominał o okropnościach komunizmu.

\section{F. Niemcy}

Po latach socrealistycznych produkcji propagandowych, realizowanych w Niemieckiej Republice Demokratycznej, czyli komunistycznym wschodnim państwie niemieckim pozostającym w totalnej zależności od Związku Sowieckiego, kinematografia niemiecka dopiero po upadku Muru Berlińskiego (1989 r.) i połączeniu państw niemieckich (1990 r.) mogła ukazać prawdziwe oblicze NRD-owskiego totalitaryzmu. Do najwybitniejszych osiągnięć w tym zakresie należał nagrodzony Oscarem w 2006 r. dla najlepszego filmu nieanglojęzycznego obraz Życie na podsłuchu ${ }^{108}$. Przedstawiał on dyktaturę i terror komunistyczny poprzez losy oficera tajnych służb, śledzącego dysydenckiego pisarza. Inwigilacja, donosy, gra pozorów, łamanie sumień, podwójna moralność, kompromisy wobec totalitarnej władzy tworzyły wizerunek przygnębiającej egzystencji w niemieckim państwie komunistycznym i stanowiły jego totalną krytykę. W lżejszej, bo komediowej formie została ona wcześniej wyrażona w znakomitym filmie Good Bye Lenin! ${ }^{109}$, podkreślającym iluzoryczność komunistycznego ustroju, nachalną indoktrynację, wszechobecne kłamstwo, a przede wszystkim znaczenie propagandy. Dramatyczne przypomnienie bestialstwa czerwonoarmistów zbiorowo gwałcących Niemki stanowił wstrząsający film Kobieta $w$ Berlinie ${ }^{110}$. W pewnym

\footnotetext{
107 Zob. Gang Rosenthala, reż. N. Caranfil, 2011.

108 Zob. Życie na podstuchu, reż. F. Henckel von Donnersmarck, 2006.

109 Zob. Good Bye Lenin!, reż. W. Becker, 2003.

110 Zob. Kobieta w Berlinie, reż. M. Färberböck, 2008.
} 
sensie wolno go uznać za odkłamanie radzieckiej produkcji Pokój przychodzacemu na świat ${ }^{111}$ o rosyjskich żołnierza konwojujących ciężarną Niemkę do szpitala. Obraz Kobieta w Berlinie nawiązywał bowiem do rzeczywistych wydarzeń i potworności dokonywanych przez radzieckich żołnierzy ${ }^{112}$.

\section{KINEMATOGRAFICZNE ODSLONY WLOSKIEGO FASZYZMU}

Ruch faszystowski rozwijający się we Włoszech po pierwszej wojnie światowej, tak jak komunizm w Związku Sowieckim, po przejęciu władzy skutecznie wykorzystywał media, a więc i kino jako narzędzie indoktrynacji. W okresie dyktatorskich rządów Mussoliniego (1922-1943) dążono do całkowitego podporządkowania kinematografii polityce państwa. Rozmaite czynniki, w tym ekonomiczne, skutkowały tym, że oddziaływanie włoskiego faszyzmu na kulturę nie przybrało tak monstrualnych rozmiarów jak najpierw w ZSRR, a potem w Trzeciej Rzeszy. Niektórzy twórcy filmowi wybierali drogę swoistego kompromisu, by zajmując się tematami drugorzędnymi nie narażać się władzy, a jednocześnie nie demonstrować sprzeciwu wobec ideologii faszystowskiej ${ }^{113}$. „W rzeczywistości spośród około 700 utworów fabularnych zaledwie kilkanaście stanowiło oręż propagandowy oficjalnej władzy"114. Dzięki marginesowi twórczej wolności w przedwojennej kinematografii włoskiej rozpoczął się nowy kierunek artystyczny, nazwany neorealizmem ${ }^{115}$. Przykładami produkcji propagandowych szerzących kult wodza oraz światopogląd faszystowski były obrazy: Stara gwardia, Scypion Afrykański,

\footnotetext{
111 Zob. Pokój przychodzacemu na świat, reż. W. Naumow, A. Ałow, 1961.

112 Por. N. D a vi e s, Europa walczy 1939-1945. Nie takie proste zwycięstwo, (tłum.) E. Tabakowska, Kraków 2008, s. 432-435.

113 Por. T. Miczka, Kino włoskie, Gdańsk 2009, s. 61-69.

114 Tamże, s. 71.

115 Por. A. P i ot row s k a, Neorealizm, w: R. S y s k a (red.), Stownik filmu, Kraków 2010, s. 118-119.
} 
Pilot Luciano Serra ${ }^{116}$, propagujące szczególnie politykę imperialną i wojenną. Służyło temu również przedstawienie Mussoliniego jako nowego Garibaldiego ${ }^{117}$ oraz apoteoza podboju Abisynii ${ }^{118}$.

Włoska kinematografia powojenna zasłynęła specyficzną, realistyczną formą ukazywania problemów egzystencjalnych oraz moralnych. Filmy wojenne przypominały dramatyczne losy włoskich żołnierzy na froncie afrykańskim ${ }^{119}$, wschodnim ${ }^{120}$, a także walki toczone na Półwyspie Apenińskim ${ }^{121}$. Ekranowa biografia Mussoliniego, wyprodukowana dla telewizji w kooperacji z innymi kinematografiami ${ }^{122}$, przedstawiała całą polityczną działalność dyktatora w konwencji dramatu paradokumentalnego. Wcześniejszy obraz ${ }^{123}$ przypominał bowiem tylko ostatnie dni wodza, czyli próbę ucieczki do Szwajcarii, ujęcie i rozstrzelanie przez komunistycznych partyzantów. Okropności wojny i bestialstwo niemieckiej okupacji Rzymu bywało ukazywane poprzez nawiązanie do historii Kościoła ${ }^{124}$ oraz dziejów Stolicy Apostolskiej'25. Dramat zagłady Żydów został przypomniany w niekonwencjonalnej formie w obrazie Życie jest piękne $e^{126}$, wymykającym się klasycznej klasyfikacji, gdyż łączącym różne, $i$ to skrajne gatunki, takie jak tragedia oraz komedia. Film odbiegający od realiów historycznych i stanowiący przypowieść o afirmacji

116 Zob. Stara gwardia, reż. A. Blasetti, 1935; Scypion Afrykański, reż. G. Gallone, 1937; Pilot Luciano Serra, reż. G. Alessadrini, 1938; por. T. M i c z k a, dz. cyt., s. $72-75$.

117 Zob. Garibaldi i jego czasy, reż. S. L. Rosa, 1926; por. G. P. Brunetta, The History of Italian Cinema, Princeton 2009, s. 61.

118 Por. O. T h o m s o n, Historia propagandy, (tłum.) S. Głąbiński, Warszawa 2001, s. 381.

119 Zob. El Alamein. Na linii ognia, reż. E. Monteleone, 2002.

120 Zob. Oni szli na Wschód, reż. G. De Santis, 1965.

121 Zob. Włoski front, reż. A. Taub, 2003.

122 Zob. Mussolini i ja, reż. A. Negrin, 1985.

123 Zob. Mussolini: ostatni akt, reż. C. Lizzani, 1974.

124 Zob. Rzym miasto otwarte, R. Rossellini, 1945; Purpura i czerń, reż. J. London, 1983; Bł. Karol Gnocchi. Ojciec miłosierdzia, reż. C. T. Torrini, 2004.

125 Zob. Pius XII. Pod rzymskim niebem, reż. C. Duguay, 2010.

126 Zob. Życie jest piękne, reż. R. Benigni, 1997. 
życia wobec ideologii rasistowskiej i skrajnego nacjonalizmu stał się prekursorem nowej fali kina włoskiego ${ }^{127}$.

\section{EKRANOWE WIZERUNKI HITLERYZMU}

Reżim hitlerowski (1933-1945) efektywnie posługiwał się sztuką i mediami wizualnymi jako narzędziami propagandy oraz indoktrynacji ${ }^{128}$. Kinematografia niemiecka zgodnie ze światopoglądem nazistowskim propagowała kult wodza, ciała, siły, rasy germańskiej i wspólnoty narodu niemieckiego ${ }^{129}$.

Produkcje fabularne realizowane w Trzeciej Rzeszy spełniały głównie funkcję rozrywkową; film był więc swoistym narzędziem propagandy, mającym na celu głównie odwracanie uwagi widzów od rzeczywistych problemów i podtrzymywanie dobrych, optymistycznych nastrojów; dlatego wśród produkcji z epoki hitlerowskiej niezbyt wiele było obrazów wprost dotyczących polityki, militaryzmu, antysemityzmu, organizacji nazistowskich, wojny ${ }^{130}$. Takie tematy pozostawiono kronikom filmowym i produkcjom dokumentalnym, których nowatorska forma stanowiła silny środek oddziaływania na widzów $^{131}$. Wśród fabularnych filmów propagandowych ogromną oglądalnością cieszył się melodramatyczny obraz wojny Koncert $\dot{z} y c e^{132}$, akcentujący potęgę lotnictwa i sprawność marynarki wojennej Trzeciej Rzeszy. Zawoalowanym wizerunkiem Hitlera był film Wielki król ${ }^{133}$ o władcy Prus, Fryderyku II, jego pojmowaniu władzy i oddziaływaniu na naród. Z inspiracji i na zlecenie ministra

127 Por. T. M i c z k a, dz. cyt., s. 613-615.

128 Por. R. G. R e u th, Goebbels, (tłum.) M. Misiorny, Warszawa 1996, s. 192 , 208-209, 220.

129 Por. M. K it c h e n, Trzecia Rzesza. Charyzma i wspólnota, (tłum.) L. Otrębski, Warszawa 2012, s. 226.

130 Por. B. D r e w n i a k, Teatr i film Trzeciej Rzeszy, Gdańsk 2011, s. 288-314.

131 Por. S. B a c h, Leni. Życie i twórczość Leni Riefenstahl, (tłum.) T. Grzegorzewska, P. Grzegorzewski, Wrocław 2008, s. 123-220.

132 Zob. Koncert życzeń, reż. E. von Borsody, 1940.

133 Zob. Wielki król, reż. V. Harlan, 1942. 
propagandy, J. Goebbelsa w latach 1943-1944 zrealizowano monumentalny obraz Kołobrzeg ${ }^{134}$ nawiązujący wprawdzie do obrony tego miasta przed wojskami napoleońskimi, ale celowo fałszujący fakty. Film ukończony w styczniu 1945 r. miał bowiem ilustrować mit o heroicznej obronie i przetrwaniu. W sposób oczywisty nawiązywał do ówczesnej sytuacji militarnej Niemiec, atakowanych ze wschodu i zachodu. Informacja o zdobyciu Kołobrzegu przez Armię Czerwoną i Wojsko Polskie nie została podana do publicznej wiadomości; Goebbels zabronił bowiem jej rozpowszechniania. Filmowa fikcja miała więc wciąż górować nad realną rzeczywistością ${ }^{135}$.

Powojenna kinematografia niemiecka przedstawiała hitleryzm odmiennie, co oczywiście było skutkiem podziału politycznego i utworzenia komunistycznej NRD oraz demokratycznej RFN. Filmy produkowane w radzieckiej strefie okupacyjnej, przekształconej w NRD akcentowały winę Niemiec za rozpętanie kataklizmu wojennego i tak jak inne kinematografie bloku wschodniego podkreślały okrucieństwo hitlerowców. Przykładem takiego obrazu był film Mordercy sa wśród nas ${ }^{136}$. Zafascynowanie hitleryzmem starał się wyjaśniać obraz Brunatna pajęczyna ${ }^{137}$, natomiast genezę ludobójstwa ukazywał film Małzeństwo w mroku ${ }^{138}$. Nadzieje na sukces kinematografii wschodnioniemieckiej okazały się płonne; socrealistyczne produkcje, np. o przemysłowcach zbijających fortunę na dostawach wojennych ${ }^{139}$, czy biografia komunistycznego działacza ${ }^{140}$, okazywały się obrazami uproszczonymi, nieciekawymi, pozbawionymi wysublimowanej estetyki, a więc jawnie propagandowymi ${ }^{141}$.

Kinematografia zachodnioniemiecka, zdominowana przez komercyjne produkcje rozrywkowe o żenująco niskiej jakości, odnosząc

\footnotetext{
134 Zob. Kołobrzeg, reż. V. Harlan, W. Liebeneiner, 1945.

135 Por. R. G. R e u t h, dz. cyt., s. 410-411.

136 Zob. Mordercy są wśród nas, reż. W. Staudte, 1946

137 Zob. Brunatna pajęczyna, reż. W. Staudte, 1949.

138 Zob. Matżeństwo w mroku, reż. K. Maetzig, 1947.

139 Zob. Rada bogów, reż. K. Maetzig, 1950.

140 Zob. Na barykadach Hamburga, reż. K. Maetzig, 1954.

141 Por. J. Płażewski, dz. cyt., s. 233-235.
} 
się do hitleryzmu uwypuklała natomiast takie wydarzenia $\mathrm{z}$ historii Trzeciej Rzeszy, które miały narzucić jej dwuznaczną interpretację i jakby wskazywać okoliczności łagodzące i usprawiedliwiające kolaborację z reżimem ${ }^{142}$. Pokazywała więc w przesadnej skali wrogość wojskowych, zarówno żołnierzy, jak i generałów, wobec Hitlera ${ }^{143}$. Taka konwencja zdaje się dominować i we współczesnej kinematografii zjednoczonych Niemiec. Podkreśla ona przede wszystkim fakty świadczące o sprzeciwianiu się hitleryzmowi przez niektóre osoby i środowiska. Film Sophie Scholl. Ostatnie dni ${ }^{144}$ przypominał dzieje małej monachijskiej organizacji studenckiej Biała Róża, kolportującej w latach 1942-1943 ulotki nawołujące do obalenia reżimu nazistowskiego, a przede wszystkim ukazywał jedyną kobietę opozycjonistkę, której zaangażowanie polityczne wynikało z moralności i wrażliwości chrześcijańskiej. Wcześniej kinematografia zachodnioniemiecka wyprodukowała obraz Biała Róża ${ }^{145}$; wartość późniejszej ekranowej biografii S. Scholl polegała na wykorzystaniu w tworzeniu scenariusza zachowanych protokołów przesłuchań przez Gestapo, ujawnionych dopiero po udostępnieniu akt NRD-owskiej Stasi ${ }^{146}$. Dzieje Georga Elsera, który w listopadzie 1939 r. w Monachium samotnie przygotował zamach na Hitlera, przedstawiał wstrząsający obraz 13 minut $^{147}$ akcentujący fanatyzm i okrucieństwo hitlerowców.

Za osobną kategorię filmów należy uznać obrazy przedstawiające historię zamachu stanu i spisku oficerów Wehrmachtu mającego na celu zabicie Hitlera w lipcu 1944 r. w kwaterze głównej, znajdującej się w Gierłoży pod Kętrzynem. Do nowszych filmów poświęconych tej tematyce należy Zamach w Wilczym Szańcu ${ }^{148}$ oraz Walki-

\footnotetext{
142 Por. tamże, s. 235-236.

143 Zob. 08/15, reż. P. May, 1954-1955; Canaris, reż. A. Weidenmann, 1954; Generał diabła, reż. Helmut Käutner, 1955.

144 Zob. Sophie Scholl. Ostatnie dni, reż. M. Rothemund, 2005.

145 Zob. Biała Róża, reż. M. Verhoeven, 1982.

146 Por. Sophie Scholl : https://pl.wikipedia.org/wiki/Sophie_Scholl (dostęp: 8.03.2017).

147 Zob. 13 minut, reż. O. Hirschbiegel, 2015.

148 Zob. Zamach w Wilczym Szańcu, reż. J. Baier, 2004.
} 
ria ${ }^{149}$; sensacyjna konwencja, dynamicznie i dość wiernie ukazująca przebieg zamachu, jakby w zawoalowany sposób prezentuje nieudolność spiskowców, a zarazem niezbyt wyraźnie akcentuje ewolucję ich motywacji, wynikającej nie ze sprzeciwu i opozycji wobec nazizmu, ale z militarnej klęski Niemiec ${ }^{150}$. Powtarzającym się filmowym motywem są także ostatnie dni Trzeciej Rzeszy i jej wodza. Upadek ${ }^{151}$ oraz Bunkier Hitlera ${ }^{152}$ ukazywały nie tylko ostateczną porażkę dyktatora, lecz również klęskę społeczeństwa poddanego krwawej tyranii. Specyficzny nurt omawianej kinematografii stanowiły obrazy ilustrujące wojenne męstwo żołnierzy niemieckich oraz podkreślające dramat młodych ludzi rozdzieranych dylematem posłuszeństwa bezsensownym rozkazom, specyficznym rozumieniem poczucia obowiązku i patriotyzmu, a zdrowym rozsądkiem i wolą życia. Stalingrad ${ }^{153}$ oraz remake filmu Most ${ }^{154}$, tak jak wcześniejszy Okręt ${ }^{155}$ pozbawione były zbędnego patosu i kreśliły realistyczny wizerunek wojny jako tragedii niszczącej wszystkich jej uczestników. Dramat cywilów uciekających z Prus Wschodnich w głąb Rzeszy, którzy stali się ofiarami największej w dziejach katastrofy morskiej ${ }^{156}$, stanowił zarazem sugestywny obraz totalitaryzmu oraz śmiercionośnego fanatyzmu. Należy jeszcze zauważyć, że kinematografia niemiecka podejmowała kooperację z twórcami z innych krajów i wspólnie z nimi zrealizowała szereg obrazów przypominających o zagładzie Żydów ${ }^{157}$.

Filmy niemieckie o hitleryzmie, choć dotyczą dramatu Holocaustu, potworności wojny, zmagań militarnych, opozycji antynazistowskiej,

\footnotetext{
149 Zob. Walkiria, reż. B. Singer,2008;

150 Por. A. B u 11 o c k, Hitler. Studium tyranii, (tłum.) T. Evert, Warszawa 1997, s. 614-615, 629-643.

151 Zob. Upadek, reż. O. Hirschbiegel, 2004

152 Zob. Bunkier Hitlera, reż. G. Schaefer, 1981.

153 Zob. Stalingrad, reż. J. Vilsmaier, 1993.

154 Zob. Most, reż. W. Panzer, 2008.

155 Zob. Okręt, reż. W. Petersen, 1981.

156 Zob. Gustloff. Rejs ku śmierci, reż. J. Vilsmaier, 2008.

157 Zob. Europa, Europa, reż. A. Holland, 1990; Getto, reż. A. Juzenas, 2006; Fatszerze, reż. S. Ruzowitzky, 2007.
} 
upadku Trzeciej Rzeszy, to jednak niezbyt wyraziście akcentują przyczyny masowego poparcia dla Hitlera, a przede wszystkim pomijają kwestię popularności i akceptacji nazistowskiego światopoglądu w kraju o bardzo długiej i bogatej tradycji chrześcijańskiej. Nie ukazują więc procesu i przyczyn odchodzenia społeczeństwa niemieckiego od tradycyjnych wartości ukształtowanych przez chrystianizm. Redukowanie genezy totalitaryzmów wyłącznie do przypomnienia idei, haseł i kontekstów politycznych oraz ekonomicznych, bez uwzględnienia odniesień do religii, a szczególnie do chrześcijaństwa, nie daje pełnego obrazu rzeczywistości, a nawet ją fałszuje i przekłamuje ${ }^{158}$. Pomija bowiem istotny wymiar ludzkiej psychiki i duchowości, która odrzucając chrystianizm otwiera się na inny światopogląd o charakterze fantazyjnym i religiopodobnym ${ }^{159}$.

\section{ZAKOŃCZENIE}

Celem prezentowanego studium było nakreślenie ewolucji filmowych obrazów europejskich totalitaryzmów XX wieku, które skutecznie wykorzystywały film jako efektywne narzędzie propagandy, indoktrynacji i manipulacji. Sugestywność ruchomych obrazów silnie pobudzających wyobraźnię oraz mocno oddziałujących na emocje w znacznym stopniu przyczyniała się do kształtowania postaw oczekiwanych przez władze, a więc do uległości i posłuszeństwa wobec polityki państwa i jego przywódców. Koniecznie należy jednak zaakcentować, że upadek sowieckiego komunizmu, włoskiego faszyzmu oraz niemieckiego hitleryzmu, nie oznaczał automatycznie pokazywania całkowitego i bezwzględnego potępienia

158 Por. M. B u r l e i g h, Trzecia Rzesza. Nowa historia, (tłum.) G. Siwek, Kraków 2010, s. 269-284.

159 Por. N. G o o d r i c k - C 1 a r k e, Okultystyczne źródła nazizmu, (tłum.) J. Prokopiuk, Warszawa 2001, s. 283-286; P. S z u p p e, Nazistowski mistycyzm w polskojęzycznej literaturze przedmiotu, Warszawa 2005, s. 104-105; M. H e s e m a n n, Religia Hitlera, (tłum.) A. Walczy, Warszawa 2011, s. 427-445; R. S a 1 a R o s e, Hitler, w: Taż, Krytyczny słownik mitów i symboli nazizmu, (tłum.) Z. Jakubowska, A. Rurarz, Warszawa 2006, s. 109-115. 
ich funkcjonariuszy. Późniejsze filmowe przedstawienia dróg usprawiedliwienia dla współpracowników reżimu oraz bierności obywateli utwierdziły model dominacji państwa nad sumieniem, a polityki nad moralnością. W zmienionych warunkach ustrojowych kino nadal bywa instrumentem określonej polityki historycznej oraz propagandy politycznej państw mających w swej nieodległej historii doświadczenia totalitaryzmu. Znamiennym tego przykładem był niemiecki serial Nasze matki, nasi ojcowie ${ }^{160}$ oraz rosyjski film Rok $1612^{161}$. Nieprawdziwe ekranowe wizje faktów i wydarzeń, jeśli są podporządkowane aktualnym interesom politycznym, to stanowią zarówno zagrożenie, wynikające z wprowadzania kłamliwych komunikatów do przestrzeni medialnej kształtujących opinię publiczną, jak i są wyzwaniem dla odbiorców, by je konfrontować z prawdą historyczną.

Film określany jako aktorski film fikcji, wytwór wyobraźni twórców, głównie reżysera i scenarzysty oraz zespołu aktorskiego i ekipy realizacyjnej ${ }^{162}$, choć stanowi w warstwie narracyjnej swoistą fantazję, to jednak może i powinien być analizowany w odniesieniu do prawdy o człowieku i ludzkich dziejach. Istotne zastrzeżenie, odnoszące się do definicji filmu fabularnego: „Oparcie opowiadanej historii na autentycznych zdarzeniach, użycie autentycznych scenerii czy zastosowanie poetyki filmu dokumentalnego nie zmieniają statusu rodzajowego filmu"163, nie wyklucza jednak analizowania go jako przekazu medialnego także poprzez pryzmat dobra oraz piękna. Iluzja może bowiem stanowić element destrukcyjny wobec prawdy, cel realizacji niektórych produkcji fabularnych z założenia oraz intencji bywa nieprawy, a forma wybranych komunikatów fabularnych może wypaczać interpretowanie świata ${ }^{164}$. Do zadań teologii środków społecznego przekazu, traktującej film jako komunikat

\footnotetext{
160 Zob. Nasze matki, nasi ojcowie, reż. Ph. Kadelbach, 2013.

161 Zob. Rok 1612, reż. W. Chotinienko, 2007.

162 Zob. Film, w: E. S z c z ę s n a (red.), Słownik pojęć i tekstów kultury, Warszawa 2002, s. 73-74.

163 Film, film fabularny, w: Słownik pojęć..., dz. cyt., s. 73.

164 Por. K. C z u b a, Katolickie podstawy etyki dziennikarskiej, Toruń 2007, s. $68,75,90$.
} 
medialny, należy więc nie tyle wskazanie jego wartości estetycznej jako dzieła sztuki kinematograficznej, ile raczej refleksja o człowieku jako twórcy, nadawcy i odbiorcy przekazów medialnych, jak również ich ocena etyczna ${ }^{165}$, uwzględniająca cel, istotę oraz rozmaite okoliczności tworzenia i rozpowszechniania określonych obrazów; w przypadku przedstawionego studium odnosiło się to do mających charakter propagandowy fabularnych wizji totalitaryzmów europejskich XX wieku.

\section{The Images of the Twentieth Century Totalitarianism as They Evolved in Film and TV Productions Summary}

The author presents the evolution of the cinematic images of twentieth century totalitarianism in selected European feature films as well as in television productions. He analyses the rendition of images of communism in the Soviet, Polish, Slovak, Czech, Romania, and German films. He also tackles the place of propaganda in films made in the fascist Italy and then in Nazi Germany. In that context, he points to the elements of propaganda in modern cinema of the states that have gone through different stages of totalitarianism.

Słowa kluczowe: film, telewizja, propaganda, obrazy totalitaryzmów, komunizm

Keywords: film, TV, propaganda, images of totalitarianism, communism

Nota o autorze: Grzegorz Łęcicki, dr hab., prof. UKSW, apologetyk, teolog mediów i teolog kultury; kierownik Katedry Teologii Środków Społecznego Przekazu; badacz mediów audiowizualnych, głównie filmów fabularnych oraz seriali telewizyjnych.

\section{Bibliografia:}

A. Adamski, G. Łęcicki, Teologia mediów i komunikacji-na styku nauko mediach oraz nauk teologicznych, „Studia Medioznawcze”, nr 2 (65) 2016, s. 17.

165 Por. A. A d a m s k i, G. Łę c i c k i, Teologia mediów i komunikacji..., art. cyt., s. 17. 
Andrew C., Gordijewski O., KGB, tłum. R. Brzeski, Warszawa 1999.

Baberowski J., Czerwony terror. Historia stalinizmu, (tłum.) J. Antkowiak, Warszawa 2009.

Bach S., Leni. Życie i twórczość Leni Riefenstahl, (tłum.) T. Grzegorzewska, P. Grzegorzewski, Wrocław 2008.

Beevor A., Druga wojna światowa, (tłum.) G. Siwek, Kraków 2013.

Bullock A., Hitler. Studium tyranii, (tłum.) T. Evert, Warszawa 1997.

Burleigh M., Trzecia Rzesza. Nowa historia, (tłum.) G. Siwek, Kraków 2010.

Cieśliński M., Polska Kronika Filmowa. Podglądanie PRL-u, Olszanica-Warszawa 2016.

Cieśliński M., Piękniej niż w życiu. Polska Kronika Filmowa 1944-1994, Warszawa 2006.

Courtois S., Zbrodnie komunizmu, (tłum.) A. Nieuważny, w: Czarna ksiegga komunizmu. Zbrodnie, terror, prześladowania, Warszawa 1999, s. 25-26.

Czuba K., Katolickie podstawy etyki dziennikarskiej, Toruń 2007.

Davies N., Europa walczy 1939-1945, (tłum.) E. Tabakowska, Kraków 2008.

Davies N., Europa walczy 1939-1945. Nie takie proste zwycięstwo, (tłum.) E. Tabakowska, Kraków 2008.

Demby Ł., Harmonia świata. Twórczość filmowa Nikity Michałkowa, Kraków 2009.

Dominiczak H., Organy bezpieczeństwa PRL w walce z Kościołem katolickim 1944-1990 w świetle dokumentów MSW, Warszawa 2000.

Drewniak B., Teatr i film Trzeciej Rzeszy. W systemie hitlerowskiej propagandy, Gdańsk 2011.

Goban-Klas T., Cywilizacja medialna, Warszawa 2005.

Goodrick-Clarke N., Okultystyczne źródła nazizmu, (tłum.) J. Prokopiuk, Warszawa 2001,

Grzelak C., Kresy w czerwieni. Agresja Zwiazku Sowieckiego na Polskę w 1939 roku, Warszawa 2001.

Hesemann M., Religia Hitlera, (tłum.) A. Walczy, Warszawa 2011.

Holzer J., Europa wojen 1914-1945, Warszawa 2008.

Kenez P., Odkłamana historia Związu Radzieckiego, (tłum.) A. Górska, Warszawa 2008.

Kersten K., Europa do drugiej wojnie światowej, w: A. Mączak (red.), Historia Europy, Wrocław 1997, s. 754-755.

Kitchen M., Trzecia Rzesza. Charyzma i wspólnota, (tłum.) L. Otrębski, Warszawa 2012.

Kula M., Religiopodobny komunizm, Kraków 2003.

Lubelski T., Historia niebyła kina PRL, Kraków 2012. 
Łazarz M., Czterej pancerni i pies. Przewodnik po serialu i okolicach, Wrocław 2006.

Łęcicki G., Cenzura w Polsce Ludowej: propaganda, manipulacja, destrukcja, „Kwartalnik Nauk o Mediach”, 2015 nr 2: http://knm.uksw.edu.pl/cenzura-w-polsce-ludowej-propaganda-manipulacja-destrukcja/ (data dostępu: 28.02.2017).

Łęcicki G., Małżeństwo i rodzina w nauczaniu oraz doświadczeniu Kościoła, Sandomierz 2011.

Łuczak M., Miś czyli świat wedtug Barei, Warszawa 2007.

Małek E., Wawrzyńczyk J., Kultura rosyjska. Postacie, wydarzenia, symbole, daty, Warszawa 2001.

Marples D. R., Historia ZSRR od rewolucji do rozpadu, (tłum.) I. Scharoch, Wroclaw 2006.

Miczka T., Kino włoskie, Gdańsk 2009.

Moorhouse R., Pakt diabłów. Sojusz Hitlera i Stalina, (tłum.) G. Siwek, Kraków 2015.

Pajewski J., Pierwsza wojna światowa 1914-1918, Warszawa 2005.

Piotrowska A., Neorealizm, w: Słownik filmu, R. Syska (red.), Kraków 2010, s. 118-119.

Piotrowski P. K., Kultowe seriale, Warszawa 2011.

Płażewski J., Historia filmu 1895-2005, Warszawa 2010.

Płużański T., Lista oprawców, Warszawa b.r.w.

Replewicz M., Stawka większa niż kłamstwo, Warszawa 2015.

Reuth R. G., Goebbels, (tłum.) M. Misiorny, Warszawa 1996.

Sala Rose R., Hitler, w: R. Sala Rose, Krytyczny słownik mitów i symboli nazizmu, (tłum.) Z. Jakubowska, A. Rurarz, Warszawa 2006, s. 109-115.

Sokołow B., Prawdy i mity Wielkiej wojny Ojczyźnianej 1941-1945, (tłum.) J. Strogonowa, A. Sawinkow, Kraków 2013.

Szczęsna E. (red.), Słownik pojęć i tekstów kultury, Warszawa 2002.

Szuppe P., Nazistowski mistycyzm w polskojęzycznej literaturze przedmiotu, Warszawa 2005.

Śmiałowski P., Tadeusz Janczar. Zawód: aktor, Warszawa 2007.

Thomson O., Historia propagandy, (tłum.) S. Głąbiński, Warszawa 2001.

Wojnicka J., Dzieci XX Zjazdu. Film w kulturze sowieckiej lat 1956-1968, Kraków 2012.

Wołkogonow D., Lenin. Prorok raju, apostoł piekła, (tłum.) M. Antosiewicz, Warszawa 2006.

Wołkogonow D., Stalin. Wirtuoz kłamstwa, dyktator myśli, (tłum.) M. Antosiewicz, Warszawa 2006. 